\title{
Geochemical evidences of trace metal anomalies for finding hydrocarbon microseepage in the petroliferous regions of the Tatipaka and Pasarlapudi areas of Krishna Godavari Basin, India
}

\author{
Rasheed M A*, Lakshmi M, Rao P L S, Kalpana M S, Dayal A M and Patil D J \\ Microbiology Laboratory, Petroleum Geochemistry Group, National Geophysical Research Institute (Council of Scientific \\ and Industrial Research), Uppal Road, Hyderabad 500007, India
}

(C) China University of Petroleum (Beijing) and Springer-Verlag Berlin Heidelberg 2013

\begin{abstract}
The long-term seepage of hydrocarbons, either as macroseepage or microseepage, can set up near-surface oxidation reduction zones that favor the development of a diverse array of chemical and mineralogical changes. The bacterial oxidation of light hydrocarbons can directly or indirectly bring about significant changes in the values of $\mathrm{pH}$ and $\mathrm{Eh}$ of the surrounding environment, thereby also changing the stability fields of the different mineral species present in that environment. The paper reports the role of hydrocarbon microseepage in surface alterations of trace metal concentrations. In this study trace metal alterations were mapped that appear to be associated with hydrocarbon microseepages in the oil/ gas fields. A total of 50 soil samples were collected near oil and gas fields of the Tatipaka and Pasarlapudi areas of the Krishna Godavari Basin, Andhra Pradesh. The soil samples were collected from a depth of 2-2.5 $\mathrm{m}$. The paper reports the chemical alterations associated with trace metals in soils that are related to hydrocarbon microseepages above some of the major oil and gas fields of this petroliferous region. Trace metals, such as scandium $(\mathrm{Sc})$, vanadium $(\mathrm{V})$, chromium $(\mathrm{Cr})$, cobalt $(\mathrm{Co})$, nickel $(\mathrm{Ni})$, copper $(\mathrm{Cu})$, zinc $(\mathrm{Zn})$, barium $(\mathrm{Ba})$ and strontium $(\mathrm{Sr})$, in soil samples were analyzed using inductively coupled plasmamass spectrometry (ICP-MS). The concentrations of Sc ( 8 to $40 \mathrm{mg} / \mathrm{kg}$ ), V (197 to $489 \mathrm{mg} / \mathrm{kg}$ ), $\mathrm{Cr}$ (106 to $287 \mathrm{mg} / \mathrm{kg}$ ), Co (31 to $52 \mathrm{mg} / \mathrm{kg}$ ), Ni (65 to $110 \mathrm{mg} / \mathrm{kg}$ ), Cu (88 to $131 \mathrm{mg} / \mathrm{kg}$ ), Zn (88 to $471 \mathrm{mg} / \mathrm{kg}$ ), Ba (263 to $3,091 \mathrm{mg} / \mathrm{kg}$ ) and $\mathrm{Sr}$ (119 to $218 \mathrm{mg} / \mathrm{kg}$ ) were obtained. It was observed that the concentrations of trace elements were tremendously increased when they were compared with their normal concentrations in soils. The analysis of adsorbed soil gas showed the presence of high concentrations of $\Sigma \mathrm{C}_{2+}\left(\mathrm{C}_{2} \mathrm{H}_{6}, \mathrm{C}_{3} \mathrm{H}_{8}\right.$ and $n-\mathrm{C}_{4} \mathrm{H}_{10}$ ) ranging from 7 to $222 \mu \mathrm{g} / \mathrm{kg}$ respectively. Integrated studies of trace elements over adsorbed light gaseous hydrocarbons $\left(\Sigma \mathrm{C}_{2+}\right)$ anomalies showed good correlation with the existing oil and gas wells. The carbon isotopic composition of $\delta^{13} \mathrm{C}_{1}$ of the samples ranges between $-36.6 \%$ to $-22.7 \%$ (Pee Dee Belemnite) values indicate thermogenic origin, which presents convincing evidence that the adsorbed soil gases collected from these sediments are of catagenetic origin. The increase in the concentrations of trace metals near oil/gas producing areas, suggests a soil chemical change to a reducing environment, presumably due to the influence of hydrocarbon microseepage, which could be applied with other geoscientific data to identify areas of future hydrocarbon exploration in frontier areas.
\end{abstract}

Key words: Hydrocarbons, microseepage, trace metal alterations, adsorbed soil gas, Krishna Godavari Basin

\section{Introduction}

Surface geochemical prospecting for hydrocarbons comprises investigation of near surface soils/sediments for occurrence of hydrocarbons that may indicate the location of subsurface petroleum reservoirs. Surface geochemical

*Corresponding author. email: drrasheedmicro@gmail.com

Received August 17, 2011 methods are based on the premise that the component hydrocarbons gases $\left(\mathrm{CH}_{4}, \mathrm{C}_{2} \mathrm{H}_{6}, \mathrm{C}_{3} \mathrm{H}_{8}\right.$ and $\left.n-\mathrm{C}_{4} \mathrm{H}_{10}\right)$ migrate to the surface from the sub-surface petroleum accumulations through faults and fractures and leave their signatures in the near surface soils. Many hydrocarbon migration mechanisms such as diffusion, effusion, advection with moving waters and permeation have been proposed and studied by various workers (Price, 1986; Tedesco, 1995; Schumacher and Abrams, 1996). These light gaseous hydrocarbons migrate 
vertically to the surface and get adsorbed in the near surface soil matrix (Jones and Drozd, 1983; Klusman, 1993; Tedesco, 1995; Kalpana et al, 2010; Schumacher and LeSchack, 2002). These light gaseous hydrocarbons may be detected either directly (adsorbed soil gas or free gas) or indirectly (microbial indicators, trace element geochemistry) through the geochemical changes they induce and an anomaly at the surface can be reliably related to a petroleum accumulation at a deeper level. The long-term seepage of hydrocarbons, either as macroseepage or microseepage, can set up nearsurface oxidation reduction zones that favor the development of a diverse array of chemical and mineralogical changes (Donovan, 1974; Petrovic et al, 2008; Khan and Jacobson, 2008). Some bacteria utilize hydrocarbon gases as their sole source of food and are found to be enriched in the near surface soils/sediments above oil and gas reservoirs, hence the bacteria are used as indicators for finding oil and gas reservoirs (Rasheed et al, 2011). The bacterial oxidation of light hydrocarbons can directly or indirectly bring about significant changes in the $\mathrm{pH}$ and Eh of the surrounding environment, thereby also changing the stability fields of the different mineral species present in that environment. These changes result in the precipitation or dissolution and remobilization of various mineral species and elements, such that the rock column above a leaking petroleum accumulation becomes significantly and measurably different from laterally equivalent rocks (Pirson, 1969; Oehler and Sternberg, 1984; Price, 1986). It is also believed that hydrocarbons along with inorganic components associated with oil are continuously migrating to the surface which forms the basis for surficial petroleum investigations with regard to trace metals (Petrovic et al, 2008). The alterations occur because of leaking hydrocarbon. Staunton (2002) has reviewed some of the interactions of metals with soil organic matter. The effect of organic matter may be by interaction due to their adsorption properties and complexation capacity, or indirectly because of the modification of mineral surface properties with organo-mineral complexes being formed. Trace elements in soils have various origins which include lithogenic elements that are directly inherited from the lithosphere (parent material); anthropogenic elements are direct or indirect results of human activities and pedogenic elements are of lithogenic and anthropogenic origins but their distribution in soil horizons and soil particles are changed due to mineral transformation and other pedogenic processes. Soils consists of a heterogeneous mixture of different organic and organomineral substances, clay minerals, (hydrous) oxides of $\mathrm{Al}, \mathrm{Fe}$ and $\mathrm{Mn}$ and other solid components, as well as a variety of soluble substances. The binding mechanisms for trace metals are therefore complex and vary with the composition of the soil, soil acidity and redox conditions. The complexity of all possible reactions occurring in soil includes dissolution, sorption, complexation, migration, precipitation, occlusion, diffusion, binding by organic substances, absorption \& sorption by microbiota and volatilization. All these processes are governed by several soil properties of which $\mathrm{pH}$ and redox potential are known to be the most important and any changes in these parameters affect most of the processes regulating the speciation of any metal in soil (Kabata-Pendias, 1993; Calmano et al, 1993). The metal ions will be adsorbed by soils and their constituents by several mechanisms like nonspecific cation-exchange, specific adsorption, co-precipitation and organic complexation (Gast, 1979). The metal ions will also be adsorbed on the surface of the soil colloids like humus polymers, clay minerals and oxides.

Recent research in soil science has revealed that changes in $\mathrm{pH}$ and Eh have an enormous effect on chemical and biological processes in the soil substrate. Surface geochemical surveys typically do not measure $\mathrm{Eh}$ and $\mathrm{pH}$ as standard procedure. Petroleum microseepage into the soil substrate causes several chemical reactions and microbial oxidation of hydrocarbons and also causes decreases in Eh and $\mathrm{pH}$. Mineral stability in any environment is dependent on, and is a function of $\mathrm{pH}$ and Eh. Hydrocarbons, migrating into the near-surface soils destabilizes many compounds and increases the solubility of the trace and minor elements. Many metal elements are highly soluble in acid solutions but will be precipitated as oxides and hydroxides with increasing $\mathrm{pH}$. Oxidation-reduction potential plays an important role on the mobility of elements. Research is lacking for utilization of $\mathrm{pH}$ and conductance as geochemical indicator of hydrocarbon microseepage. Anomalous amounts of vanadium, chromium, nickel, cobalt, manganese mercury, copper, molybdenum, uranium, zinc, lead and zirconium are positive indicators of petroleum deposits (Duchscherer, 1984). The migrating hydrocarbons create a reducing environment in the soil and subsurface, which increases the solubility of many trace and major elements.

This paper reports the chemical alterations associated with trace metals in soils that are related to hydrocarbon microseepages above some of the major oil and gas fields of petroliferous region of Tatipaka and Pasarlapudi areas of Krishna Godavari Basin, India.

\section{Geology of the study area}

The Krishna-Godavari Basin is a pericratonic rift margin system with an Archean basement on the east coast of the Indian Peninsula (Kotha, 2002). It covers an area of 28,000 $\mathrm{km}^{2}$ on land and $24,000 \mathrm{~km}^{2}$ offshore up to $200 \mathrm{~m}$ deep (Gupta, 2006). The basin lies between $15^{\circ} 30^{\prime}$ to $17^{\circ} \mathrm{N}$ latitudes and $80^{\circ}$ to $82^{\circ} 30^{\prime} \mathrm{E}$ longitudes. Geographically, the basin lies between Kakinada in the northeast and Ongole in the southwest. Archean crystalline basement and Upper Cretaceous sedimentary outcrops demarcate the basin margin. The basin extends southeast into the deep water of the Bay of Bengal. A significant part of the onshore basinal area is covered by recent alluvium. Outcrops in the basin margin area includes the Permean Chintalapudi sandstone, Cretaceous to Jurassic Gollapalli sandstone, Raghavapuram shale and Tirupati sandstone exposed around Dwaraka Tirumala area of the West Godavari district. The Rajahmundry sandstone outcropping near the Rajahmundry and Dowleswaram areas are red, feldspathic, ferruginous and laterised sandstone of Miocene age, which is equivalent to the Ravva formation of the offshore area. 
The basin is divided into the Krishna, East Godavari and West Godavari depressions separated by basement highs at Bapatla and Tanuku horsts, respectively (Rao, 1993). The East Godavari sub-basin is further divided into the Mandapeta Graben, Narsapur-Razole High and Amalapuram High. The Matsyapuri-Palakollu and Mori faults are the two major NE-SW faults. The West Godavari sub-basin is sub-divided into the Gudivada and Bantumilli graben, separated by the Kaza-Kaikaluru horst (Kumar, 1983). The tertiary alluvium sediments brought by the Godavari delta system attained greater thickness south of the Matsyapuri-Palakollu fault as a result of continuous subsidence and growth fault related tectonics (Sanyal et al, 1998). The depositional environment varies from continental to lagoonal, littoral, infraneritic, deltaic and marine conditions. The sediments yield rich faunal assemblages like arenaceous foraminifera (Ammobaculites sp., Ammodiscoides sp., etc.), Trigonia, Inoceramus, Lima, Pecten, Belemnites, Helicoceras, Cardita, Lamellibranchs and Gastropods (Sastri et al, 1973). A geological location map of the Krishna-Godavari Basin is shown in Fig. 1.

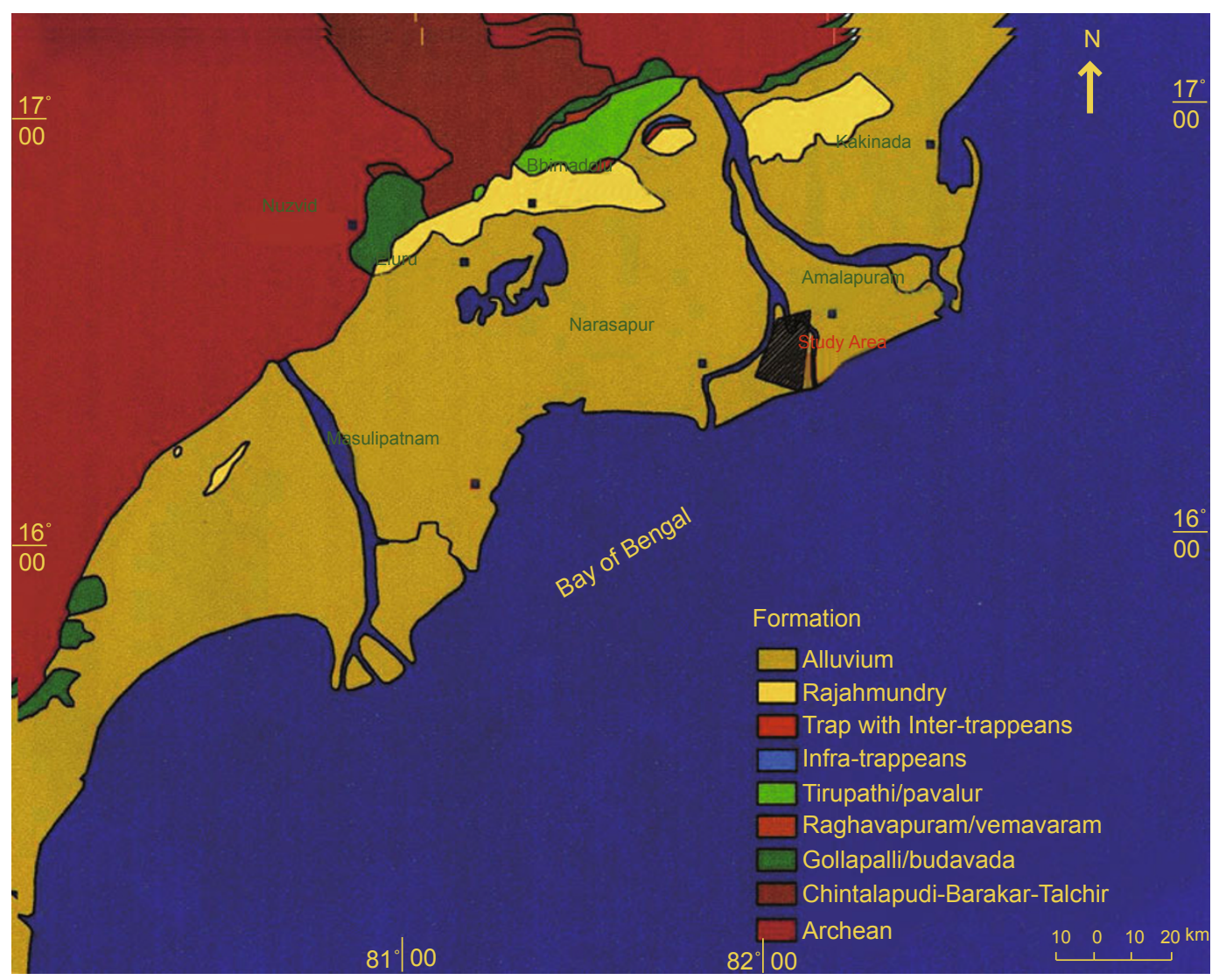

Fig. 1 Geological location map of the study area of the Krishna-Godavari Basin

\subsection{Sampling}

A total of 50 soil samples were collected from selected sites near oil and gas fields of the Tatipaka, Pasarlapudi areas of the Krishna Godavari Basin, Andhra Pradesh. The soil samples were collected from a depth of 2-2.5 m using a hollow metal pipe by manual hammering to the required depth. About $500 \mathrm{~g}$ of core soil samples collected were wrapped in aluminum foil and sealed in poly-metal packs used for analysis of adsorbed soil gases and trace element concentrations. The samples were sealed in plastic bags with their sample number and global positioning system (GPS) locations marked. Areas which were disturbed or excavated soils that were contaminated with hydrocarbons, chemicals or animal wastes and swamps \& areas under water shed were avoided for sampling purposes. While collecting the samples, rocks, coarse materials, plant residues, and animal debris have been excluded (Rasheed et al, 2008).

\subsection{Light hydrocarbon analysis using gas chromatography}

The light gaseous hydrocarbons were extracted from the soil samples using a gas extraction system (Horvitz, 1981). $1 \mathrm{gm}$ of $63 \mu$ particle size soil sample was used to extract light gaseous hydrocarbons after acid treatment in glass degasification apparatus and subsequent analyses on gas chromatograph (GC) and gas chromatograph-combustionisotope ratio mass spectrometer ( $\mathrm{GC}-\mathrm{C}-\mathrm{IRMS})$ analysis for samples that had higher concentrations of hydrocarbons. During acid treatment, the dominant gas released was $\mathrm{CO}_{2}$ which was trapped in $\mathrm{KOH}$ solution. The light gaseous hydrocarbons were collected by water displacement in a graduated tube fitted with rubber septa. The volume of 
desorbed gas was recorded and $500 \mu \mathrm{L}$ of desorbed gas sample was injected into gas chromatograph (Varian CP 3380) fitted with a Porapak Q column, equipped with a flame ionization detector. The gas chromatographs were calibrated using external standards with known concentrations. The quantitative estimation of light gaseous hydrocarbon constituents in each sample was made using peak area measurements and a correction for moisture content on a wet basis was also applied. The hydrocarbon concentration values of individual hydrocarbons from methane through pentane are expressed in parts per billion $(\mu \mathrm{g} / \mathrm{kg})$.

\subsection{Physico-chemical analysis}

The physico-chemical properties, such as $\mathrm{pH}$, electrical conductivity (EC), total dissolved solids (TDS) and oxidationreduction potential (Eh) in soil samples, were analyzed on $\mathrm{pH} / \mathrm{EC} / \mathrm{Eh}$ Bench top meter (Thermo Electron Corp. Orion 5 star).

\subsection{Analysis of trace elements using inductively coupled plasma mass spectrometer (ICP-MS)}

The analysis of trace elements in the soil samples was carried out using ICP-MS (Perkin-Elmer Sciex Elan DRC II) at the National Geophysical Research Institute, Hyderabad. The chemical analyses of the soil samples were carried out using ICP-MS (Perkin-Elmer Sciex Elan DRC II). An ICPMS is a type of mass spectrometry based on coupling together an inductively coupled plasma as a method of producing ions (ionizations) with a mass spectrometer as a method of separating and detecting ions. ICP-MS is highly sensitive and capable of determination of a range of metals and several non-metals at concentrations that are less than one part in $10^{12}$.

The soil samples were dried and sieved using a $63 \mu$ sieve. A sample size of $0.05 \mathrm{~g}$ was taken in a Teflon beaker. $10 \mathrm{~mL}$ of acid mixture (7:3:1) comprising of $\mathrm{HF}, \mathrm{HNO}_{3}$ and $\mathrm{HClO}_{4}$ was added to the sample and left over night at room temperature, and the samples were dried at $200{ }^{\circ} \mathrm{C}$ on a hotplate. $20 \mathrm{~mL}$ of $1: 1 \mathrm{HNO}_{3}$ and double distilled water were added and heated for 10 minutes on a hotplate at $200{ }^{\circ} \mathrm{C}$. Finally, rhodium as internal standard was added and made up to $200 \mathrm{~mL}$ with distilled water. A precision of $1 \%-7 \%$ relative to standard deviation and comparable accuracy was obtained by this method. The analytical procedures and protocols followed at NGRI are the same as given in Naqvi et al (2006), Balaram et al (1996) and Rao and Govil (1995).

\section{Results and discussion}

\section{$3.1 \mathrm{pH}$}

The $\mathrm{pH}$ of the soils in the study area ranges from 5.72 to 8.88 with an arithmetic mean of 8.18 and standard deviation of 0.58 (Table 1). Most of the soil samples are alkaline in nature. It is observed that, the $\mathrm{pH}$ ranges between 6 and 8 above the oil and gas accumulations, and it is below 6 around the periphery. The acidic nature of soils prevents adsorption of hydrocarbons (Horvitz, 1985). The highly acidic nature around the periphery involves in the mobilization of certain major and minor and trace elements to the oxidizing areas and precipitation as oxides and hydroxides. The concentration of certain elements above oil field areas and depletion in the soils around the periphery is the main cause of acidity of the soils. The soil acidity is the main reason for creating an oxidation-reduction potential or front. The $\mathrm{pH}$ is observed to be 7 to 8 around gas producing areas; around oil producers, it is 8 to 8.5 and around non-producing oil/gas areas, it is greater than 8.5 (Rao, 2006). The pHs in the present study area are observed to be in the range for a gas producing area, which is true as the majority of the wells in the KG Basin are gas producers.

Table 1 The statistical analysis of physico-chemical properties in soil samples of the study area

\begin{tabular}{cccc}
\hline & $\mathrm{pH}$ & $\begin{array}{c}\mathrm{EC} \\
\mu \mathrm{S} / \mathrm{cm}\end{array}$ & $\begin{array}{c}\text { Eh (ORP) } \\
\mathrm{mV}\end{array}$ \\
\hline Minimum & 5.72 & 76 & 142 \\
Maximum & 8.88 & 3490 & 295 \\
Arithmetic mean & 8.18 & 888 & 205 \\
Median & 8.38 & 417.5 & 207 \\
Standard deviation & 0.58 & 963 & 32 \\
\hline
\end{tabular}

\subsection{EC}

The amount of soluble salts in soils is generally estimated by measuring the electrical conductivity of aqueous soil extracts. The EC of the near surface soils in the study area ranges from 76 to $3,490 \mu \mathrm{S} / \mathrm{cm}$ at $25{ }^{\circ} \mathrm{C}$, with an arithmetic mean of $888 \mu \mathrm{S} / \mathrm{cm}$ and a standard deviation of $963 \mu \mathrm{S} / \mathrm{cm}$ (Table 1). The specific conductance is a supporting parameter for recognizing gas microseepages. Electrical conductivity is found to be a useful parameter to locate gas and gas associated oil reservoirs. There is a recognizable increase in electrical conductivity above areas of gas accumulation (Heemstra et al, 1979), but little effect over oil and barren areas.

\subsection{Eh}

Petroleum microseepage causes several chemical reactions in the near surface soil. The near surface change of Eh and $\mathrm{pH}$ conditions in response to light hydrocarbon microseepage and its microbial oxidation drives a localized redistribution of trace elements. Oxidation-reduction potential plays an important role in the mobility of elements. The Eh in the near surface soils of the study area ranged from 142 to $295 \mathrm{mV}$ with arithmetic mean of $205 \mathrm{mV}$ and standard deviation of 32 $\mathrm{mV}$ (Table 1). Eh measures the tendency of an environment to oxidize or reduce substrates and the values decrease from oxidizing to reducing environments (Maier et al, 2009).

Petroleum seeps into the soil substrate altering the existing Eh and $\mathrm{pH}$ conditions, and causes a reducing environment, where solubility increases and transportation of trace metals occurs. The reducing environment created 
by the petroleum oxidizes and mobilizes various elements. The most common carbonates cannot be oxidized, $\mathrm{CaCO}_{3}$ and $\mathrm{MgCaCO}_{3}$ for instance are fully oxidized and cannot be further oxidized. However, siderite can be oxidized. Chemical solubility is a prerequisite for physical mobility of the trace metals (Robinson et al, 2005). Trace metals become more mobile under acidic and reducing conditions as long as slightly soluble metal sulfides do not precipitate (Rennert and Mansfeldt, 2006). Given a steady pH, even the reducing conditions enhance the mobility of trace metals (Charlatchka and Cambier, 2000; Chuan et al, 1996). The hydrodynamic flow in the soil moves the solubilized elements around although they do not necessarily leave the reduced area. Concentration into the "anomalous" areas occurs where reducing groundwater is low in $\mathrm{pH}$ and $\mathrm{Eh}$ and intermingles with groundwater of higher Eh and $\mathrm{pH}$. This results in deposition of carbonate, sulfide, phosphate, and oxide minerals, which incorporate the trace elements into the compounds (Tedesco, 1995).

\subsection{Trace element geochemistry}

Trace element concentrations $(\mathrm{mg} / \mathrm{kg})$ in soil samples of the study area are given in Table 2 . The trace metals scandium $(\mathrm{Sc})$, vanadium $(\mathrm{V})$, chromium $(\mathrm{Cr})$, cobalt $(\mathrm{Co})$, nickel $(\mathrm{Ni})$, copper $(\mathrm{Cu})$, zinc $(\mathrm{Zn})$, barium $(\mathrm{Ba})$ and strontium $(\mathrm{Sr})$ are considered for the study and the concentrations of each of the trace elements varied in the following manner. The concentrations of each of the trace elements Sc (8 to $40 \mathrm{mg} /$ $\mathrm{kg}$ ), V (197 to $489 \mathrm{mg} / \mathrm{kg}$ ), Cr (106 to $287 \mathrm{mg} / \mathrm{kg}$ ), Co (31 to $52 \mathrm{mg} / \mathrm{kg}$ ), $\mathrm{Ni}$ (65 to $110 \mathrm{mg} / \mathrm{kg}$ ), $\mathrm{Cu}(88$ to $131 \mathrm{mg} / \mathrm{kg})$, $\mathrm{Zn}(88$ to $471 \mathrm{mg} / \mathrm{kg}$ ), Ba (263 to $3,091 \mathrm{mg} / \mathrm{kg}$ ) and $\mathrm{Sr}(119$ to $218 \mathrm{mg} / \mathrm{kg}$ ). The concentration of trace metals along with normal values in soil samples of the study area is given in Table 3. The concentrations of trace elements in normal soils are as follows for $\mathrm{Sc}(7 \mathrm{mg} / \mathrm{kg}), \mathrm{V}(90 \mathrm{mg} / \mathrm{kg}), \mathrm{Cr}(70 \mathrm{mg} /$ $\mathrm{kg})$, Co (8 mg/kg), Ni (50 mg/kg), Cu (30 mg/kg), Zn (90 $\mathrm{mg} / \mathrm{kg}), \mathrm{Ba}(500 \mathrm{mg} / \mathrm{kg})$ and $\mathrm{Sr}(250 \mathrm{mg} / \mathrm{kg}$ ) (Bowen, 1979). It was observed that the concentrations of trace elements were tremendously increased when compared with normal concentrations in soils.

The concentration distribution maps of these trace elements in the study area can be seen with their respective composite anomaly maps with $\Sigma \mathrm{C}_{2+}$ (Figs. 2, 3, 4, 5, 6, 7, 8 and 9). The trace elements anomalies are located in the Tatipaka and Pasarlapudi areas and west of Pasarlapudi lanka. Trace elements concentration distribution showed good correlation with the existing oil and gas wells. Increased amounts of soluble $\mathrm{Ni}, \mathrm{V}, \mathrm{Cu}, \mathrm{Cr}, \mathrm{Zn}$ and $\mathrm{Co}$ have been observed in the reducing environment caused by the seepage of hydrocarbons. In the reducing environment, solubility of metals increases and transport occurs. Due to hydrodynamic flow in the soil, the solubilized elements move around, although they do not leave the reducing area (Tedesco, 1995). When oil migrated, the trace-elements within the oil also migrate, and these can get added to trace metals of soil and they may experience the same chemical changes as those of soil trace metals in the hydrocarbon seepage areas. Vanadium and nickel are the only heavy metal elements that occur in crude oils in appreciable quantities as soluble organic complexes (Al-Shahristani and Al-Atyia, 1972). Other trace elements such as $\mathrm{Mn}, \mathrm{Cr}, \mathrm{Cu}, \mathrm{Zn}, \mathrm{Sb}, \mathrm{Se}, \mathrm{Br}$, I anomalies related to hydrocarbon reservoirs have been reported by Clark et al (2003). Because a boundary is formed between the reducing and oxidizing zone by the deposition of carbonate, oxide and sulphide minerals, several metals including $\mathrm{Ni}, \mathrm{V}$, $\mathrm{Cu}, \mathrm{Cr}, \mathrm{Zn}$ and $\mathrm{Co}$ are mobilized in soils and accumulated around the hydrocarbon anomaly when reducing conditions are created due to hydrocarbon accumulation (Nissenbaum and Swaine, 1976). Recent geochemical studies carried in Neuquen Basin of Argentina have revealed that the trace metal vanadium is transported to the surface by the uplifting of microbubbles of hydrocarbon gases. This is known from the fact that vanadium content is closely related to bacterial anomalies that feed on the seeping hydrocarbons. It is reported that the concentrations of $\mathrm{V}, \mathrm{Zn}$ and $\mathrm{Ba}$ are seen concentrated over the faults and lineaments, which might have provided the migrational pathway for their transportation (Larriestra et al, 2010). Hence, the concentrations of trace elements in the present study area, were found to be extremely high, which is evidence of hydrocarbon microseepage in the Krishna Godavari Basin.

\subsection{Integration with adsorbed soil gases}

Trace elements concentrations have been used as indirect indicator for hydrocarbon microseepage (Madhavi et al, 2011). This study compares the trace elements with direct detection of adsorbed light hydrocarbon soil gas concentrations and explains how the trace elements concentrations vary near hydrocarbon anomalies. The compositional correlation is fundamental to understanding the link between trace element concentrations and hydrocarbon anomalies. The adsorbed soil gas analysis showed the presence of high concentrations of $\Sigma \mathrm{C}_{2+}\left(\mathrm{C}_{2} \mathrm{H}_{6}, \mathrm{C}_{3} \mathrm{H}_{8}\right.$ and $\left.n-\mathrm{C}_{4} \mathrm{H}_{10}\right)$ ranged between 7 to 222 $\mu \mathrm{g} / \mathrm{kg}$. Integrated maps of trace elements over adsorbed light gaseous hydrocarbons $\left(\Sigma \mathrm{C}_{2+}\right)$ anomalies showed good correlation with the existing oil and gas wells (Figs. 2, 3, 4, $5,6,7,8$ and 9). The adsorbed soil gas anomalies were seen in the centre and also adjacent to the trace metal anomalies. Most of the trace metal anomalies (Cr, V, Co and $\mathrm{Zn}$ ) were observed in north-east and south-west parts of the study area, and scanty in the middle part of the study area except for $\mathrm{Cu}$ and Ni. By observing the composite maps of hydrocarbons and trace elements, clearly indicate that trace elements are accumulated around the hydrocarbon anomalies, creating a halo pattern. The study shows that most of the trace elements follow a halo pattern encircling an apical pattern of hydrocarbon seepage indicating the presence of a reduced body in the subsurface. The composite maps of hydrocarbons and trace elements, clearly indicate that trace elements are accumulated around the hydrocarbon anomalies, creating a halo pattern. Trace elements occur as a near surface 'halo' which will be pathfinders or otherwise important in the search for hydrocarbon anomalies (Siegel, 1974). Duchscherer (1983) reported that trace element associations form organometallic compounds, are found "haloed" or concentrated over or around underlying hydrocarbon reservoirs. In the present 
Table 2 Trace element concentrations $(\mathrm{mg} / \mathrm{kg})$ in soil samples of the study area

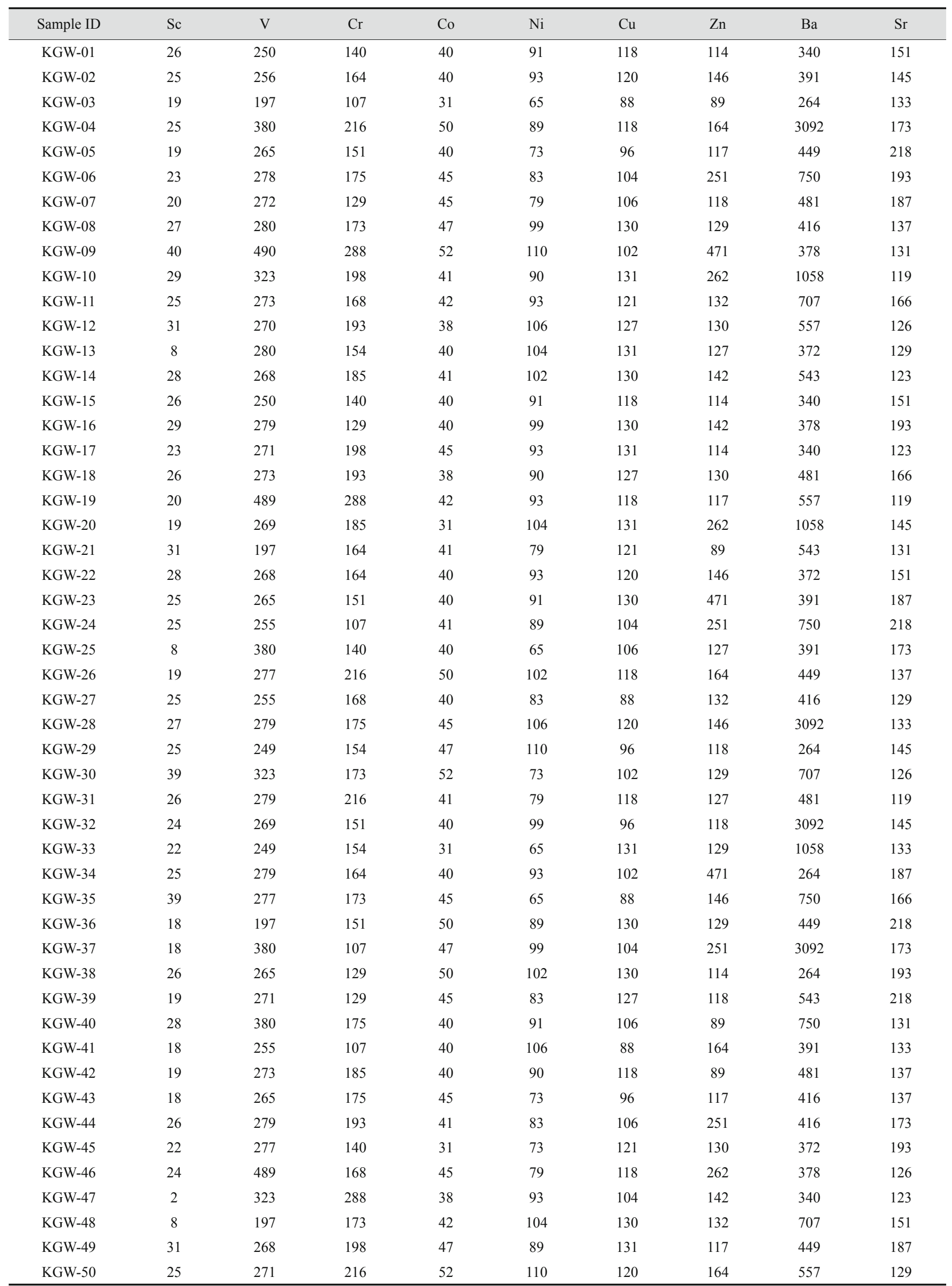


Table 3 Descriptive statistics of trace elements $(\mathrm{mg} / \mathrm{kg})$ in soil samples of the study area

\begin{tabular}{|c|c|c|c|c|c|c|}
\hline Elements & Minimum & Maximum & Average & Standard deviation & Median & Normal soil values* \\
\hline $\mathrm{Sc}$ & 8 & 40 & 24 & 7 & 25 & 7 \\
\hline $\mathrm{V}$ & 197 & 490 & 288 & 65 & 272 & 90 \\
\hline $\mathrm{Cr}$ & 107 & 288 & 171 & 41 & 168 & 70 \\
\hline $\mathrm{Co}$ & 31 & 52 & 42 & 5 & 41 & 8 \\
\hline $\mathrm{Ni}$ & 65 & 110 & 90 & 12 & 91 & 50 \\
\hline $\mathrm{Cu}$ & 88 & 131 & 115 & 14 & 118 & 30 \\
\hline $\mathrm{Zn}$ & 89 & 471 & 166 & 91 & 130 & 90 \\
\hline $\mathrm{Ba}$ & 264 & 3092 & 712 & 735 & 449 & 500 \\
\hline $\mathrm{Sr}$ & 119 & 218 & 155 & 30 & 145 & 250 \\
\hline
\end{tabular}

Notes: *Values from Bowen (1979)

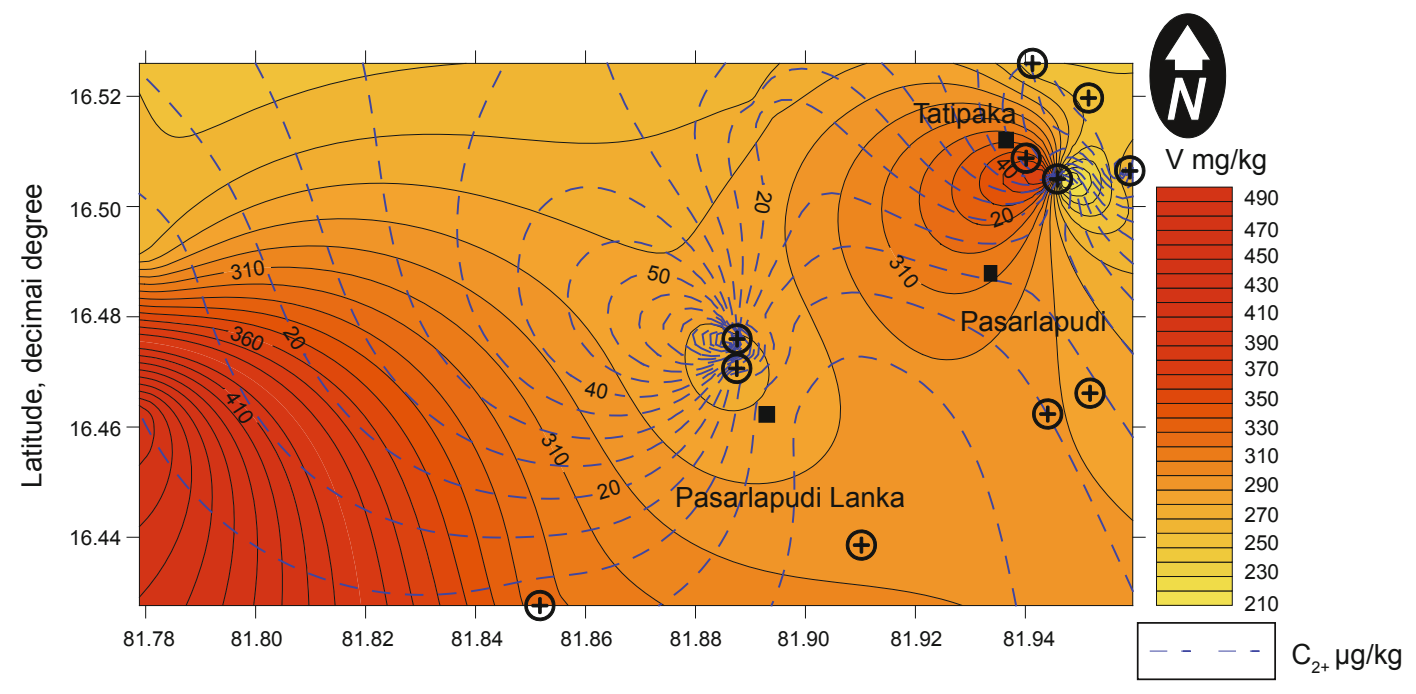

Longitude, decimal degree

$\bigoplus$ Oil/Gas wells

Fig. 2 Composite map of vanadium and adsorbed soil gas concentration in oil and gas fields of the study area

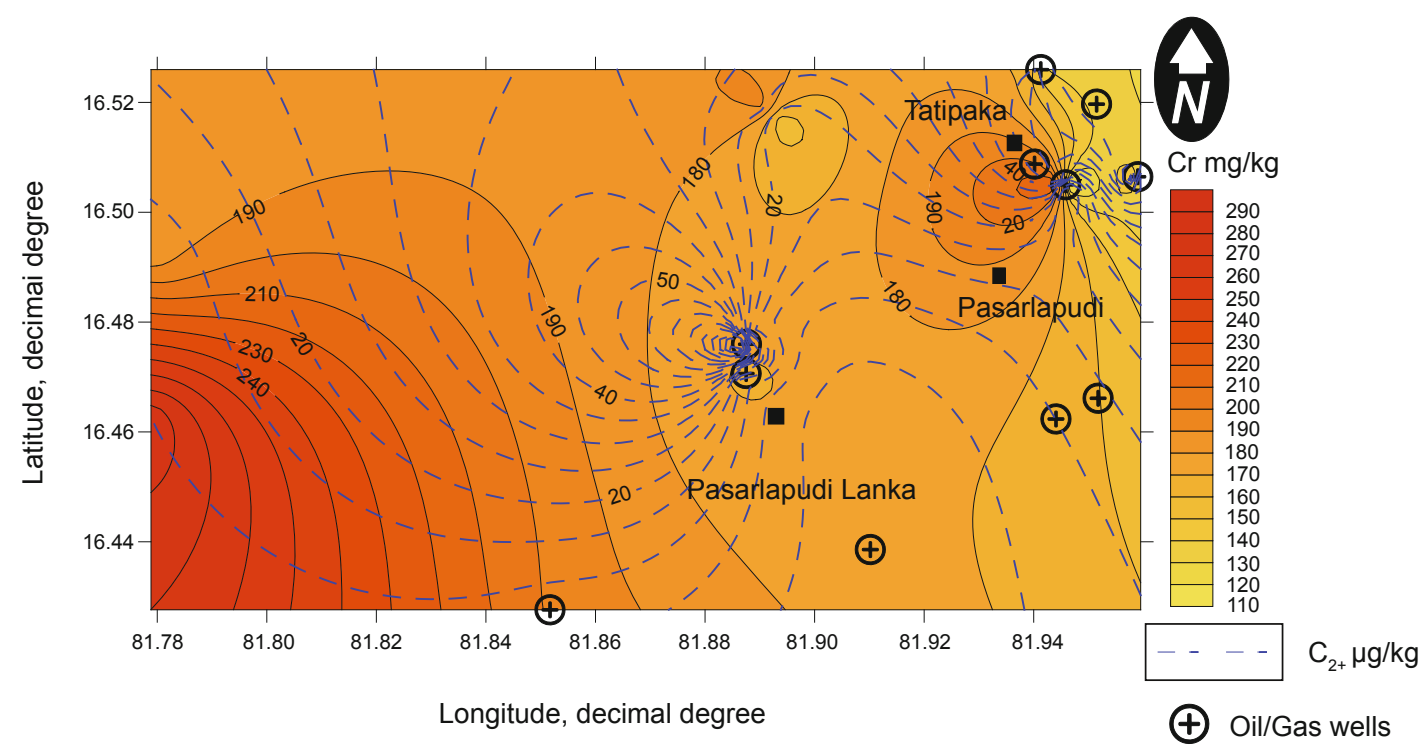

Fig. 3 Composite map of chromium and adsorbed soil gas concentration in oil and gas fields of the study area 


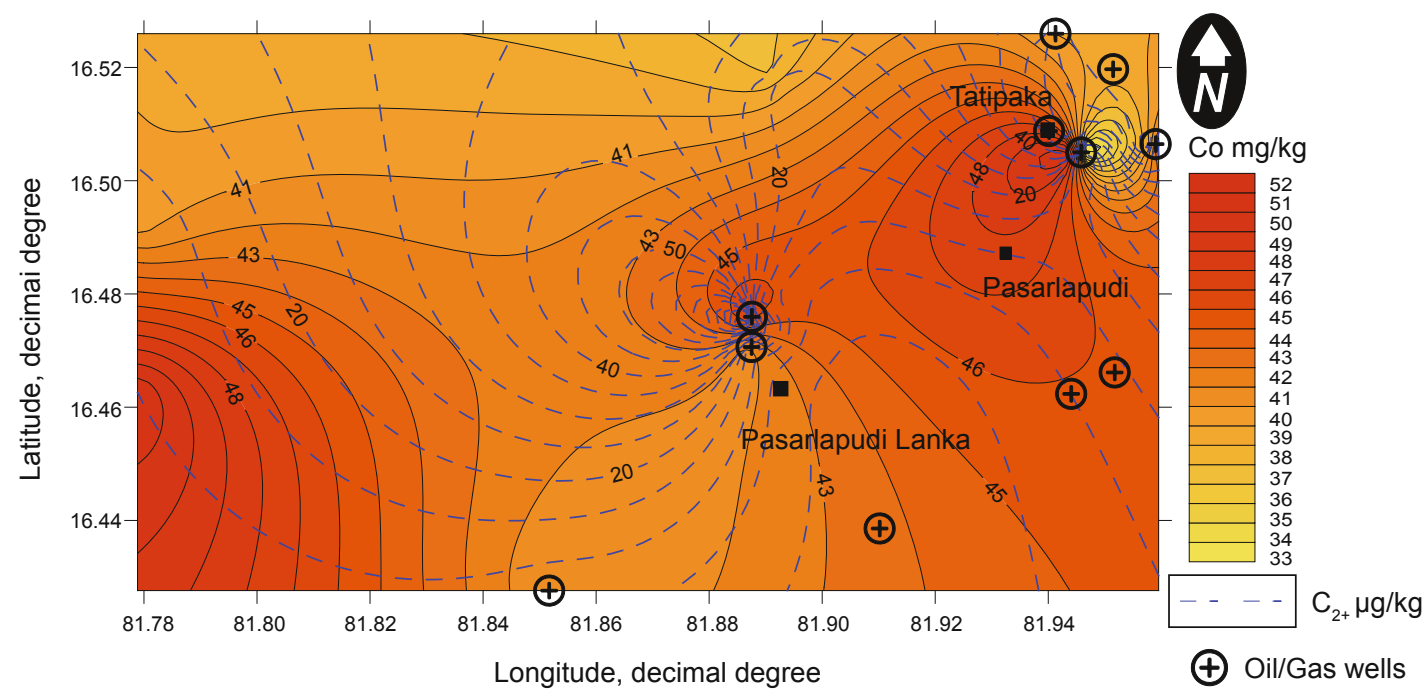

Fig. 4 Composite map of cobalt and adsorbed soil gas concentration in oil and gas fields of the study area

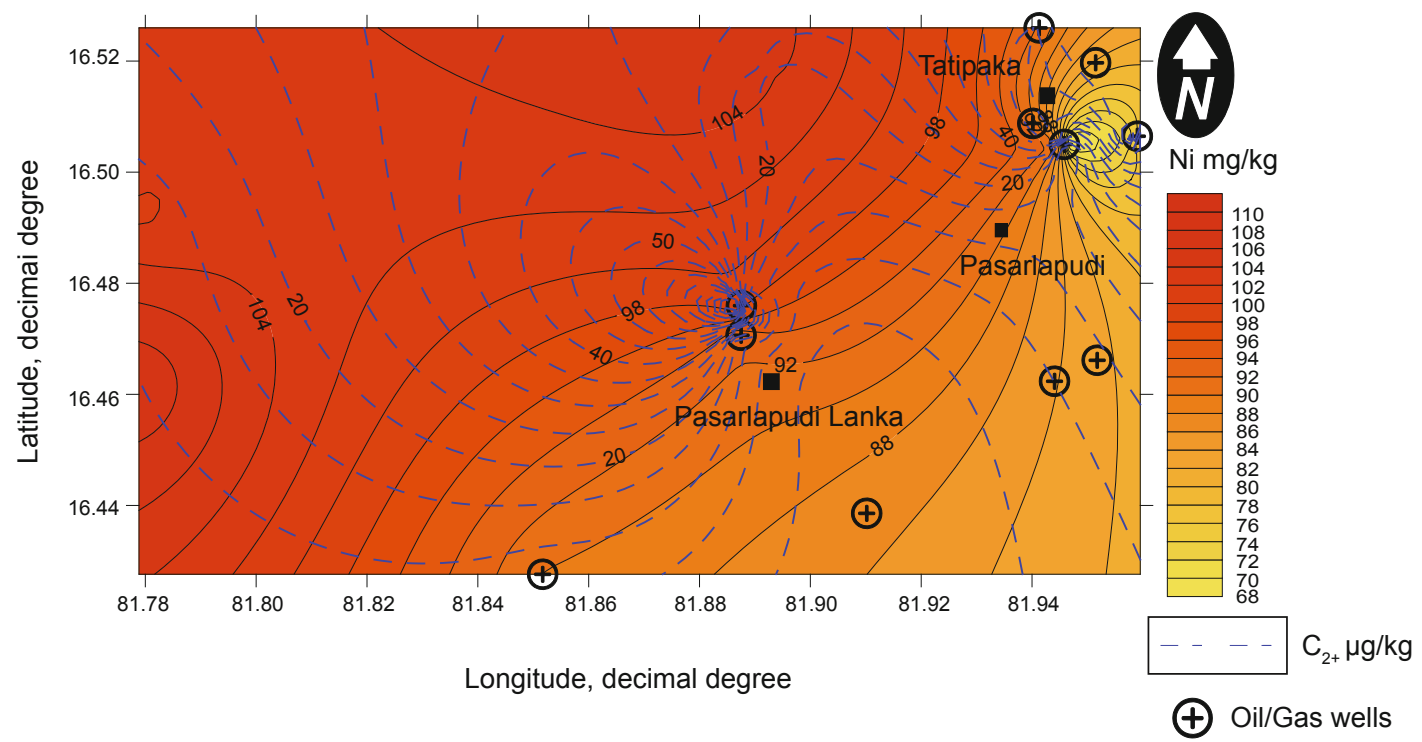

Fig. 5 Composite map of nickel and adsorbed soil gas concentration in oil and gas fields of the study area

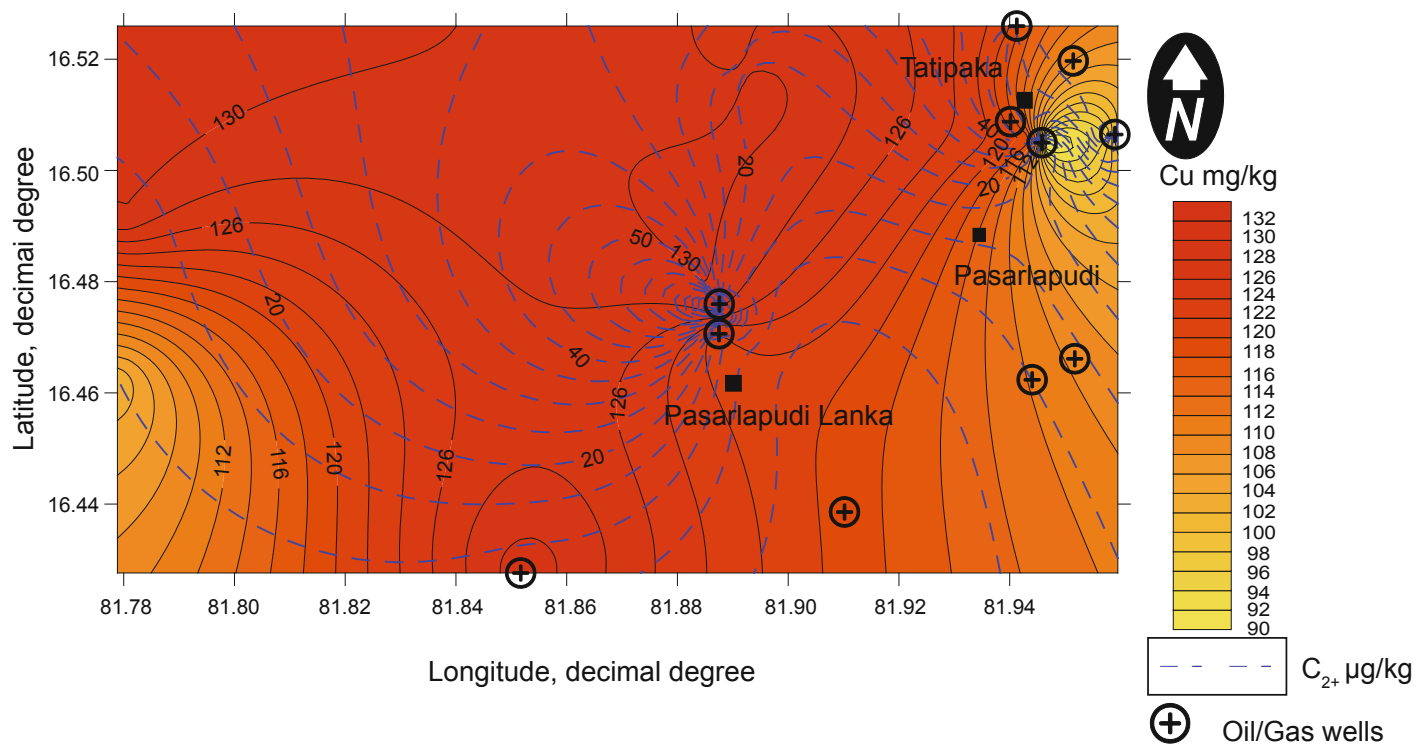

Fig. 6 Composite map of copper and adsorbed soil gas concentration in oil and gas fields of the study area 


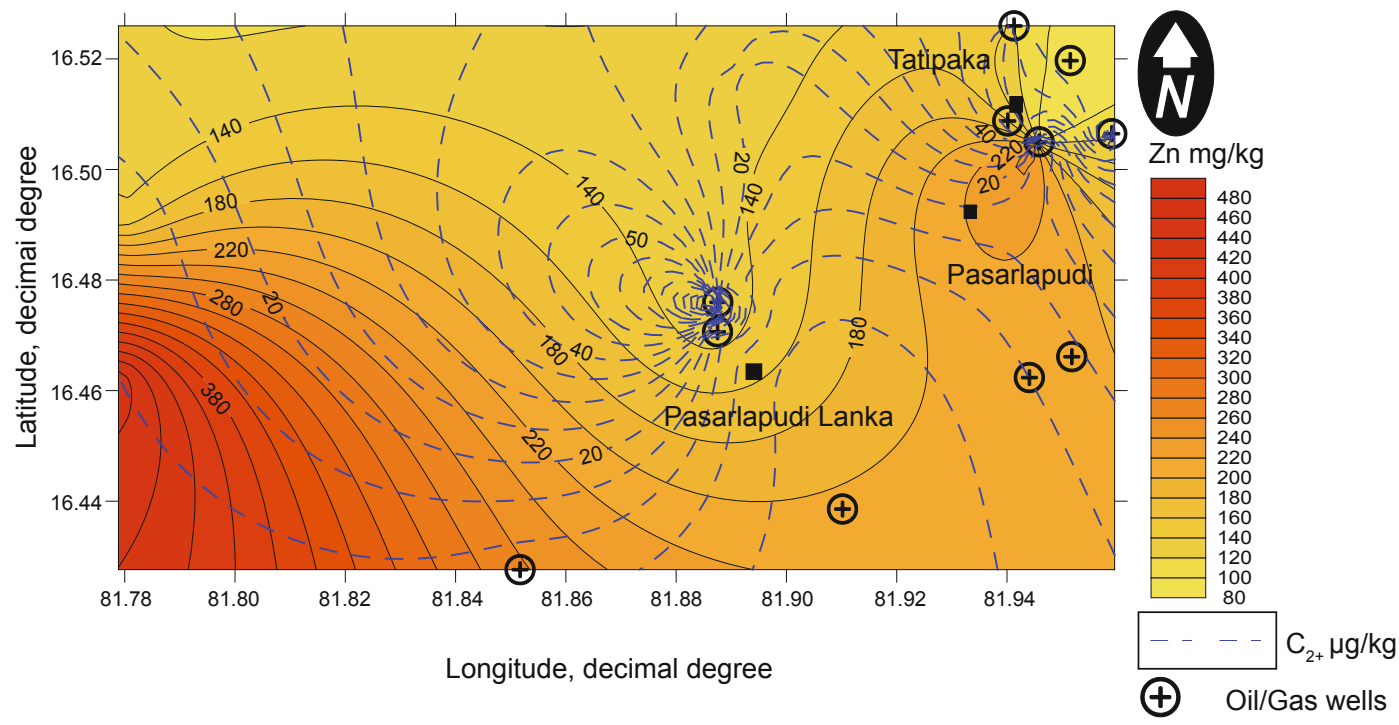

Fig. 7 Composite map of zinc and adsorbed soil gas concentration in oil and gas fields of the study area

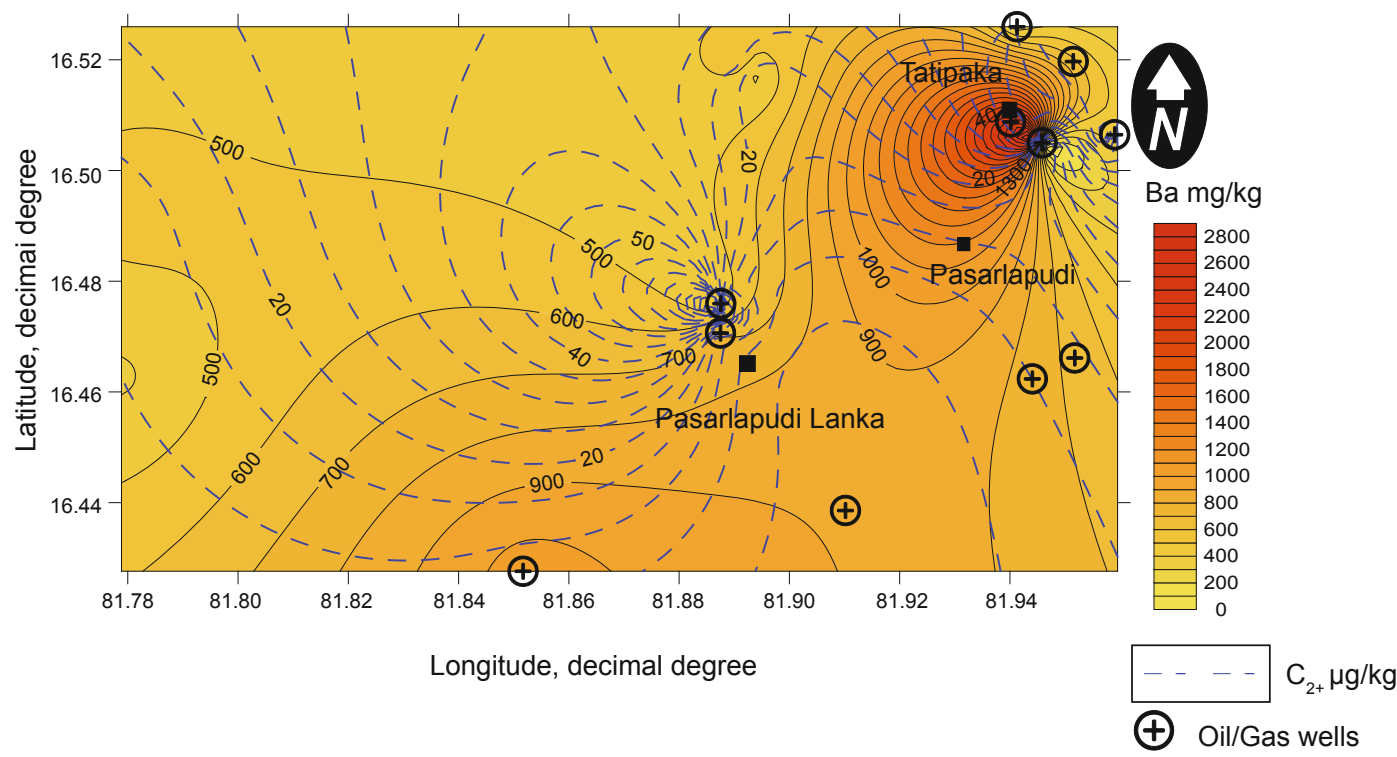

Fig. 8 Composite map of barium and adsorbed soil gas concentration in oil and gas fields of the study area

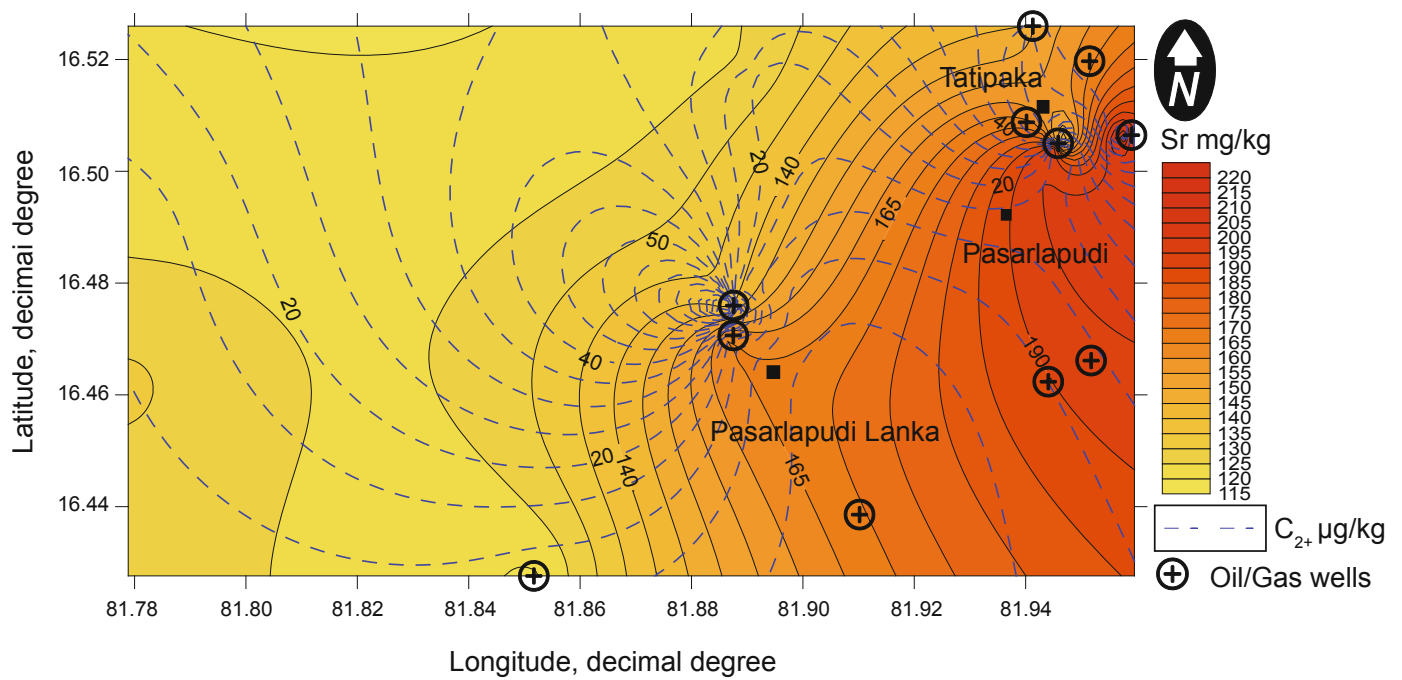

Fig. 9 Composite map of strontium and adsorbed soil gas concentration in oil and gas fields of the study area 
study area of the Krishna Godavari Basin, the concentration distribution maps of vanadium, nickel, chromium, iron, cobalt, copper and manganese showed inverse correlation whereas those of strontium and barium showed positive correlation with the migrating hydrocarbons.

The carbon isotopic composition of $\delta^{13} \mathrm{C}_{1}$ of the samples ranges between $-36.6 \%$ to $-22.7 \%$ o (PeeDee Belemnite) values indicate thermogenic origin, which presents convincing evidence that the adsorbed soil gases collected from these sediments are of catagenetic origin. Enrichment of trace elements seen around the hydrocarbon anomaly helps verify the correlation between microseepage and trace elements concentrations. That enrichment of trace elements in one or more prospective zones around hydrocarbon anomalies can suggest that trace elements may be a pathfinder or otherwise an important search tool for hydrocarbon anomalies.

\section{Conclusions}

The concentrations of trace elements showed excellent correlation with existing oil and gas wells in the study area. The anomalies of trace elements are found to be in good agreement with geological information available for the area and correlated with the major oil and gas fields of the Krishna Godavari Basin. The composite anomaly maps of $\Sigma \mathrm{C}_{2+}$ and trace elements correlate well with the underlying hydrocarbon reservoirs in the study area. The increase in the concentrations of trace metals near oil/gas producing areas, suggests a soil chemical change to a reducing environment, presumably due to the influence of hydrocarbon microseepage, which could be applied with other geo-scientific data to identify areas of future hydrocarbon exploration in the frontier areas. The trace element studies in correlation with adsorbed soil gas studies confirmed the seepage of lighter hydrocarbon accumulations from the subsurface and help in finding hydrocarbon microseepage in petroliferous regions. The experimental research work has the potential to reduce risk in petroleum exploration. This is of high significance, especially now when globally petroleum reserves replacement is becoming a challenge.

\section{Acknowledgements}

The authors Dr. M. A. Rasheed (Project Scientist) and Ms. M. Lakshmi (Senior Research Fellow) acknowledge CSIR, New Delhi and we are thankful to the Director, CSIRNational Geophysical Research Institute, Hyderabad for granting permission to publish this work. We also thank the Secretary, Oil Industry Development Board (OIDB), New Delhi for a financial grant for setting up the microbiology laboratory facility. We are grateful to Dr. Kuldeep Chandra, Former Executive Director, KDMIPE, Dehradun for his continuous support and constant guidance.

\section{References}

Al-Shahristani H and Al-Atyia M J. Vertical migration of oil in Iraqi oil fields: Evidence based on vanadium and nickel concentrations. Geochimica et Cosmochimica Acta. 1972. 36(9): 929-938

Balaram V, Ramesh S L and Anjaiah K V. New trace element and REE data in thirteen GSF reference samples by ICP-MS. Geostandards Newsletter. 1996. 20(1): 71-78

Bowen H J M. The Environmental Chemistry of the Elements. Academic Press. London, New York. 1979

Calmano W, Hong J and Förstner U. Binding and mobilization of heavy metals in contaminated sediments affected by $\mathrm{pH}$ and redox potential. Water Science and Technology. 1993. 28(8-9): 223-235

Charlatchka R and Cambier P. Influence of reducing conditions on solubility of trace metals in contaminated soils. Water, Air and Soil Pollution. 2000. 118(1-2): 143-167

Chuan M C, Shu G Y and Liu J C. Solubility of heavy metals in a contaminated soil: Effects of redox potential and $\mathrm{pH}$. Water, Air and Soil Pollution. 1996. 90(3-4): 543-556

Clark J R, Reno N V and Tompkins R. Mapping of reservoirs and subsurface structures using selective analysis of the surface chemistry of soil particles. 88th Annual Meeting of AAPG (Extended Abstract). Salt Lake City, May 11-14, 2003

Donovan T J. Petroleum microseepage at Cement, Oklahoma: Evidence and mechanism. American Association of Petroleum Geologists Bulletin. 1974. 58(3): 429-446

Duchscherer Jr W. Geochemical hydrocarbon exploration-A new/ old exploration tool. In: Proceedings of the 9th International Geochemical Exploration Symposium. Journal of Geochemical Exploration. 1983. 19(1-3): 335-336

Duchscherer Jr W. Geochemical Hydrocarbon Prospecting. Pennorthwestell Publ. Co., Tulsa, OK. 1984

Gast R G. Exchange phenomena. In: Fairbridge R W and Finkl C W (eds.), Encylopedia of Soil Science. Dowden, Hutchinson \& Ross, Stroudsburg Pa. 1979. 148-152

Gupta S K. Basin architecture and petroleum system of KrishnaGodavari Basin, east coast of India. The Leading Edge. 2006. 25(7): 830-837

Heemstra R J, Ray R M, Wesson T C, et al. Critical laboratory and field evaluation of selected surface prospecting techniques for locating oil and natural gas. Bartlesville, Oklahoma, Department of Energy, Bartlesville Energy Technology Centre, BETC/RI-78/18. 1979. 84

Horvitz L. Hydrocarbon prospecting after forty years. In: Gottleib B M (ed.). Unconventional Methods in Exploration for Petroleum and Natural Gas II. Southern Methodist University Press. Dallas, TX. 1981. 83-95

Horvitz L. Geochemical exploration for petroleum. Science. 1985. 229(4716): 821-827

Jones V T and Drozd R J. Predictions of oil or gas potential by nearsurface geochemistry. AAPG Bulletin. 1983. 67(6): 932-952

Kabata-Pendias A. Behavioural properties of trace metals in soils. Applied Geochemistry. 1993. 8(Supplement 2): 3-9

Kalpana M S, Patil D J, Dayal A M, et al. Near surface manifestation of hydrocarbons in Proterozoic Bhima and Kaladgi Basins: Implications to hydrocarbon resource potential. Journal of the Geological Society of India. 2010. 76(6): 548-556

Khan S D and Jacobson S. Remote sensing and geochemistry for detecting hydrocarbon microseepages. GSA Bulletin. 2008. 120(12): $96-105$

Klusman R W. Soil gas and related methods for natural resource exploration. John Wiley \& Sons. Chichester. 1993. 483

Kotha Y. Sedimentology and sequence stratigraphy of hydrocarbonbearing mandapeta pays: A braided fluvial reservoir, KrishnaGodavari Basin. Journal of the Geological Society of India. 2002. 60: $249-270$

Kumar S P. Geology and hydrocarbon prospects of Krishna, Godavari and Cauvery basins. Petroleum Asia Journal. 1983. 8(1): 57-65

Larriestra F, Ferrer F, Larriestra C, et al. Geochemical anomalies characterization by microbial and trace elements analysis related to hydrocarbon migration, Nequen Basin, Argentina. Search and 
Discovery (AAPG Datapages), \#40667. 2010

Madhavi T, Kalpana M S, Patil D J, et al. Evidence for a relationship between hydrocarbon microseepage and trace metal anomalies: An implication for petroleum exploration. Geosciences Journal. 2011. 15(2): 121-224

Maier R M, Pepper I L and Gerba C P. Environmental Microbiology (2nd Edition). Academic Press. 2009. 624

Naqvi S M, Khan R M K, Manikyamba C, et al. Geochemistry of NeoArchean high-Mg Basalts, boninites and Adakites from the KustagiHungund greenstone belts of the eastern Dharwar Craton (EDC): Implication for the tectonic setting. Journal of Asian Earth Sciences. 2006. 27: 25-44

Nissenbaum A and Swaine D J. Organic matter-metal interactions in recent sediments: The role of humic substances. Geochemica et Cosmochimica Acta. 1976. 40(7): 809-816

Oehler D Z and Sternberg B K. Seepage-induced anomalies, "false" anomalies, and implications for electrical prospecting. American Association of Petroleum Geologists Bulletin. 1984. 68: 1121-1145

Petrovic A, Khan S D and Chafetz H S. Remote detection and geochemical studies for finding hydrocarbon-induced alterations in Lisbon Valley, Utah. Marine and Petroleum Geology. 2008. 25(8): 696-705

Pirson S J. Geological, geophysical, and chemical modification of sediments in the environment of oil fields. In: Heroy W B (ed.), Unconventional Methods in Exploration for Petroleum and Natural Gas, Symposium 1. Dallas: Southern Methodist University Press. 1969. 159-186

Price L C. A critical overview and proposed working model of surface geochemical exploration. In: Davidson M J (ed.), Unconventional Methods in Exploration for Petroleum and Natural Gas, Symposium IV. Dallas: Southern Methodist University Press. 1986. 245-304

Rao C B. Near surface geochemical hydrocarbon prospecting in LingalaKaikalur Oil Field, Krishna District, Andhra Pradesh. Ph.D Thesis submitted to Department of Applied Geochemistry, Osmania University, Hyderabad, India. 2006

Rao G N. Geology and hydrocarbon prospects of east coast sedimentary basins of India with special reference to Krishna-Godavari Basin. Journal of the Geological Society of India. 1993. 41(5): 444-454

Rao T G and Govil P K. Merits of using barium as a heavy adsorber in major element analysis of rock samples by X-ray fluorescence: New data on ASK-1 and ASK-2 reference samples. Analyst. 1995. 120: 1279-1282

Rasheed M A, Lakshmi M, Srinu D, et al. Bacteria as indicators for finding oil and gas reservoirs: A case study of the Bikaner-Nagaur Basin, Rajasthan, India. Petroleum Science. 2011. 8(3): 264-268

Rasheed M A, Veena P M, Satish K T, et al. Geo-microbial prospecting method for hydrocarbon exploration in Vengannapalli Village, Cuddapah Basin, India. Current Science. 2008. 95(3): 361-366

Rennert T and Mansfeldt T. Release of trace metals, sulfate and complexed cyanide from soils contaminated with gas-purifier wastes: A microcosm study. Environmental Pollution. 2006. 139(1): 86-94

Robinson B, Bolan N, Mahimairaja S, et al. Solubility, mobility, and bioaccumulation of trace elements: Abiotic processes in the rhizosphere. In: Prasad M N V, Sajwan K S and Naidu R (eds.), Trace Elements in the Environment: Biogeochemistry, Biotechnology and Bioremediation. CRC Press Boca Raton. 2005. 97-110

Sanyal Dhanapani A, Onkar Prasad L M, Mane P H, et al. Eocene sedimentation and its hydrocarbon prospects, south of MatsyapuriPalakollu Fault, Krishna-Godavari Basin, India. In: Tiwari R N (ed.), Recent Researches in Sedimentary Basins. 1998. 78-90

Sastri V V, Sinha R N, Singh G, et al. Stratigraphy and tectonics of sedimentary basins on east coast of Peninsular India. AAPG Bulletin. 1973. 57(4): 655-678

Schumacher D and Abrams M A. Hydrocarbon Migration and its NearSurface Expression. AAPG Memoir. 1996. 66: 71-89

Schumacher D and LeSchack L A. Surface Exploration Case Histories: Applications of Geochemistry, Magnetics and Remote Sensing. AAPG Studies in Geology. No.48, SEG Geophysical References Series 11. 2002. 486

Siegel F R. Applied Geochemistry. John Wiley \& Sons. 1974. 139-141

Staunton S. Direct and indirect effects of organic matter on metal immobilization in soil. Developments in Soil Science. 2002. 28A: 7697

Tedesco S A. Surface Geochemistry in Petroleum Exploration. New York: Chapman \& Hall. 1995. 256

(Edited by Hao Jie) 